\title{
INDIGENOUS KNOWLEDGE WITH GENDER PERSPECTIVES ON ANIMAL HUSBANDRY PRACTICES: A CASE STUDY IN TANZANIA
}

\author{
G.H. Laswai, A.D. Maeda-Machangu, S.K. Mutayoba, E.E. Lazaro, D. Mwaseba and \\ E.S. Kimambo
}

Sokoine University of Agriculture, P.O. Box 3004, Morogoro, Tanzania

\section{SUMMARY}

A study was conducted in the pastoral, extensive and intensive agro-pastoral systems in Tanzania with the aim of analysing the indigenous knowledge of men and women on the aspects of animal husbandry and health care. Information on gender related issues, such as division of labour, decisionmaking and access to major resources was also gathered. Data was collected using direct observations, houschold interviews and discussions with groups of men and women differently. The results showed that traditional division of labour by gender in livestock production was much stronger with the pastoral than the agro-pastoral system. In the pastoral system men were responsible for managing the herd. including herding (55\%), watering (97\%) and slaughtering (71\% of respondents) of animals. Women's main roles in the herd management were milking (95\%), milk processing and marketing $(97 \%)$ and taking care of the sick and young animals. Both men and women practised local methods of managing and tackling some health problems and diseases of livestock and sometimes blended them with modern teclunologies. A list of some of the local materials and methods of applying them is given in the paper. Livestock advice and training was mainly given to men (78\%). On the other land, most of the animal husbandry practices in the intensive agro-pastoral system were shared between men and women. Men in the pastoral $(98 \%)$ and extensive agro-pastoral $(78 \%)$ communities were the owners of cattle, whereas in the intensive communities the whole family owned cattle ( $40 \%$ of the respondents). Generally, it was found that the more valuable the animal is, the less influence women lave on decision-making concerning its purchase. ownership and salc. The paper concludes that both gender and indigenous knowledge have impact on livestock productivity and recommends that they be considered in livestock devclopment projects.

\section{Keynords: Indigenous knowledge, gender, animal health and production}

\section{INTRODUCTION}

Livestock production in Tanzania is organised under two main sectors, the commercial and the traditional sectors. The traditional sector accounts for about $85 \%$ of the total livestock population, whercby the lype of animals kept are mainly indigenous breeds, which are found under three major production systems, the pastoral, extensive agro-pastoral and intensive specialised system (Shayo and Mlay. 1986; Mtenga et al.. 1992). These production systems have arisen from the socio-cultural importance given to livestock in the society. the ecological characteristics, animal ecotypes and the farming system practised by the community. The pastoral societies derive most of their sustenance and livelihood dircctly from livestock and thus livestock plays an important role in the economic, social and cultural lives of these societies. Agro-pastoral is a farming system in which crop and animal production is combined. It is the most common farming system in Tanzania and can either be extensive or intensive depending on land availability.

Several authors (Rutatora, 1995; Warner, 1991) have analysed the concept of indigenous knowledge. The term indigenous knowledge is sometimes used synonymously with the term local knowledge. Warner (1991) defined indigenous knowledge as that knowledge of the environment and procurement strategies based on intimate experience accumulated over many generations. Indigenous knowledge is believed to be knowledge unique to particular ethnic groups or societies. An understanding of the characteristics of indigenous knowledge is important in order to be able to exploit its potential for the improvement of people's livelihood. A number of developmental projects have failed or misused resources duc to disregarding of indigenous knowledge. Changing of the social and economic system of the community need well understanding of the existing knowledge and experiences. The potential benefits of integrating lessons from indigenous knowledge with modern technologies include increased production, sustainability, security and profitability of livestock. Another aspect is that of gender relations and involvement of different gender groups in development activities, decision making, ownership and control over resources. Frequently, many of extension 
services have focused on men forgetting the considerable contribution of women. In Tanzania, $51 \%$ of the human population is women and contribute about $75 \%$ of the labour force in agriculture with varying degree of involvement in livestock keeping and crop production

In order to elicit what the livestock farmers know about their animals and the affinity between sexes in perception and distribution of the family labour, a case study was carried out in three livestock production systems commonly found in Tanzania. The overall objective was to highlight the potential of indigenous knowledge, which when applied together with scientific knowledge will benefit the livestock kecpers and improve human livelihood especially women. The specific objectives were to systematically record indigenous knowledge of men and women in relation to animal husbandry and health care and analyse the family division of labour in three livestock production systems in Tanzania.

\section{METHODOLOGY}

A study was conducted in the pastoral, extensive agro-pastoral and intensive systems in Tanzania. Two regions, each with two villages were selected for each livestock production system. The regions surveyed were Morogoro and Tanga for the pastoral, Iringa and Mara for the extensive agro-pastoral and Kilimanjaro and Mbeya for the intensive system. These regions were selected because of their contrasting livestock keeping systems.

Data was collected using participatory methods and structured interviews. Group interviews were conducted with focal group of women only, men only and mixed groups. This was done in order to determine custodian of indigenous knowledge by gender. Checklist questions were used to guide discussions during the intervicws. Structured interviews were designed for the purpose of quantifying and verifying some of the data gathered during group interviews. Aspects such as gender division of labour in the houschold, indigenous knowledge in livestock pests and diseases, control and treatment of livestock disease, medicinal plant species were covered during the discussion and interviews. A sample of 20 households was selected purposively from each village for the interview. Some herbs used by the respondents as medicine for livestock were also collected and identified. The data coded and entered into the computer, using Lotus 123 data entry format and analysed using the Statistical Package for Social Sciences (SPSS) computer software. Descriptive statistics such as means, frequencies and percentages were computed and presented in the text.

\section{RESULTS AND DISCUSSION}

Indigenous knowledge on livestock breeds

In the intensive system exotic brecds were largely kept whercas in the pastoral and agro-pastoral extensive systems local breeds were commonly found. Both men and women had knowledge of identifying the different breeds and types of animals. The animals were identified mainly by colour and to some extent by name. Livestock keepers continuously selected the best animals basing on the productivity of the animal in terms of milk yield, calving rate and size of the animal. Men mainly performed selection of animals (Table1). This knowledge on performance criteria on selection was passed through from one generation to another and was necessary for sustainability of the indigenous/local breeds and high-producing animals.

\section{Indigenous knowledge on livestock management}

Grazing in open space was the major feeding system in pastoral and extensive agro-pastoral livestock production system. In this system supplementary feeding to animals was uncommon. Most farmers had substantial knowledge on the different types of plants eaten by the animals and the toxic plant types. Movement of animals during the dry season for pastures and water was commonly used ( $60 \%$ of the respondents) as a survival strategy. In the intensive system, animals were largely stall-fed. This process involved collection, carrying and feeding the animals. The respondents had knowledge of the type of the feed, quality and quantity of feed enough for the animals. This knowledge was mainly with women as were responsible for stall feeding and attending animals indoors (Table 1). In this system adequate housing for animals was crucial. The type of houses and housing materials varied from one household to another, but often times were made of locally available materials $(65 \%$ of respondents). These included poles, timber barks, bamboo trees, grasses and mud. A few respondents constructed animal houses using cement blocks and corrugated iron sheets. Men built animal houses (Tablc 1) and hence were the custodians of this knowledge. In the extensive system livestock were kept in thorn fenced enclosures (bomas), which were constructed by men (Table 1) In this case men through their indigenous knowledge identified specific species of bushes. which are suitable for construction of such enclosures. This was based on materials, which can keep for a long time without being infected by insects, such as ants. The aim was to confine the animals and kecp away wild animals during the night. 
Table 1. Livestock related gender issues in the different livestock production systems (Percent of respondents)

\begin{tabular}{|c|c|c|c|c|c|c|c|c|c|}
\hline \multirow{3}{*}{ Activity/Issue } & \multicolumn{8}{|c|}{ Livestock Production System } & \\
\hline & \multicolumn{3}{|c|}{ Pastoral } & \multicolumn{2}{|c|}{$\begin{array}{l}\text { Agro-pastoral } \\
\text { Extensive }\end{array}$} & & \multicolumn{3}{|c|}{ Agro-pastoral Intensive } \\
\hline & $\mathrm{M}^{1}$ & $\bar{F}$ & $\mathrm{~A}$ & $M$ & $\mathrm{~F}$ & A & $\mathrm{M}$ & $\mathrm{F}$ & A \\
\hline \multicolumn{10}{|l|}{ Resource Ownership } \\
\hline - land & & & & 75 & & & 23 & & 40 \\
\hline - livestock & 98 & 1.9 & & 78.4 & 133 & 84 & 30 & 6.7 & 40) \\
\hline \multicolumn{10}{|l|}{ Livestock activities } \\
\hline -animal house construction & & & & 55 & & & 45 & & \\
\hline - boma construction & 63.4 & & 5.0 & 57 & & 1.7 & & & \\
\hline - herding cattle & 55 & 5 & 3.4 & 78 & 7.0 & 23 & - & & \\
\hline - goat herding & 20.3 & 5.1 & 3.4 & 25 & & 50 & 10 & & \\
\hline - sheep herding & 20.7 & 12.1 & 3.4 & 22 & & & 22 & & \\
\hline - watering the animals & 96.6 & 1.7 & 1.7 & 22 & 10 & 1.7 & 13 & 49 & 30 \\
\hline - livestock selection & 91.8 & & 4.1 & 78 & 11 & 8.5 & 81 & 11 & 8 \\
\hline - heat diagnosis & 70.7 & & 23.6 & 68 & 9 & 14 & 10.3 & 31 & 3.4 \\
\hline - pregnancy diagnosis & 70.0 & 1.7 & 25.0 & 55 & 12 & 27 & 29.2 & 50 & \\
\hline - disease diagnosis & 74.1 & 1.7 & 20.7 & 63 & 8 & 5 & 10.3 & 31 & \\
\hline - calf rearing & 20.3 & 13.6 & 3.4 & 11 & 4.3 & 64 & 6.7 & 63 & 30) \\
\hline - Stall feeding & & & & & & & 6.7 & 63.3 & 30 \\
\hline - milking & 3.3 & 95 & & 15 & 54 & 15 & & 78 & 6.8 \\
\hline - Milk marketing & 3.3 & 96.7 & & 13 & 70 & 14 & 31 & 31 & 14 \\
\hline - Slaughtering & 70.7 & 5.2 & & 98 & & 2 & 93 & & \\
\hline - livestock advice & 77.8 & 22.2 & & 42 & 30 & 5 & 15.8 & 61.4 & 1.8 \\
\hline Work load (hours) & $6-8$ & $14-16$ & & $6-8$ & $14-16$ & & $10-12$ & $14-16$ & \\
\hline
\end{tabular}

Division of livestock related activities and other gender issues

A variation in the roles for men, women, male and female children within a family was observed between the different livestock systems (Table 1). In the pastoral and extensive agro-pastoral communities men carried out most of the activities involving the management of catle, except milking and caring of young animals, whereas in the intensive system, animals were mainly attended by women indoors. In the pastoral and intensive systems women did hand milking whereas in extensive agropastoral system men were occasionally did milking the animals. In the pastoral and extensive agropastoral systems ownership and control of animals was tightly vested in male heads of the household. Women were excluded from major decision making and control over livestock. Women commanded the food crops and poultry, which are consumed by the family, whereas men were responsible for cash crops and livestock production. On the other hand, in the intensive system the whole family $(40 \%$ of respondents) is the main owner of the family assets including livestock and both men and women make decision on the important family issues.

Indigenous knowledge on animal health care

Men in the case of pastoral (74\%) and agro-pastoral (63\%) systems and mainly women (34\%) in the intensive system had good knowledge of identifying sick animals and different disease symptoms (Table 1). Sick animals were identified mainly through skilful observation of the animals in their eating habit, skin condition and vigour. Respondents had also considerable knowledge on the methods of treatment of some of the diseases. The methods used to treat some selected livestock diseases are shown in Table 2. About $45 \%$ of the respondents used local herbs to treat retained placenta, mastitis and diarrhoea. However, none of the respondents indicated the use of local herbs to treat anthrax.

The respondents revealed also that they had a lot of knowledge regarding medicinal plants, which are used to treat the various diseases and health problems. As noted by Ole Lengisugi (1994) knowledge of plants is the most refined aspect among local peoples' knowledge. Some of the medicinal plants identified from the different communities are presented in Table 3. It can be deduced from the list of the plant species that different ethnic groups have different kind of knowledge on medicinal plants. At the same time different plants can be used to treat the same discase type depending on the part of the plant being used. According to the respondents, the use of these plants has reduced requirement for veterinary drugs as well as input costs and livestock deaths from disease attacks. 
Table 2. The type of treatment used by some of the respondents for treating selected livestock diseases

\begin{tabular}{lccc}
\hline Disease & \multicolumn{3}{c}{ Number and percent of respondents } \\
\cline { 2 - 4 } & Veterinary Drugs & Local treatment & None \\
\hline ECF & $9(45)$ & $8(40)$ & $3(5)$ \\
Anaplasmosis & $8(40)$ & $5(25)$ & $7(35)$ \\
Foot and mouth & $7(35)$ & $5(25)$ & $8(40)$ \\
Lumpy skin & $5(25)$ & $3(15)$ & $12(60)$ \\
Rinderpest & $5(25)$ & $1(5)$ & $14(70)$ \\
Anthrax & $5(25)$ & $0(0)$ & $15(75)$ \\
Retained placenta & $3(15)$ & $9(45)$ & $8(40)$ \\
Arbotion & $3(15)$ & $2(10)$ & $15(75)$ \\
Mastitis & $5(25)$ & $9(45)$ & $6(30)$ \\
Contagious Bovine Pleuroneumonia & $8(40)$ & $4(20)$ & $8(40)$ \\
Bloat & $3(15)$ & $5(25)$ & $12(60)$ \\
Constipation & $4(20)$ & $5(25)$ & $11(55)$ \\
Diarrhoea & $10(50)$ & $9(45)$ & $1(5)$ \\
\hline
\end{tabular}

numbers in parenthesis are percentages

Table 3. Some medicinal plants identified from the different communities and their uses

\begin{tabular}{|c|c|c|}
\hline Vernacular name & Scientific Name & Uses \\
\hline \multicolumn{3}{|l|}{ Chagga tribe } \\
\hline Mratune & Aloe volkensii & Oxytocic effect; wound treatment \\
\hline Iwinu & Cassia didymobotrya & Anaplasmosis \\
\hline Mfifina (bark) & Commiphora zimmermannii & Anaplasmosis \\
\hline Ifurufuru/l furufuru & Croton macrostachysis & Antihelminthic; laxative \\
\hline Mwarie/Iwarie & Bridelia micrantha & Anaplasmosis \\
\hline Kilulu/Mwulu & Albizia versicolor & Diarhoea \\
\hline Moseraka & Pentas & Antihelminthics;laxative \\
\hline Msesewe & Rawolfia caffra & Laxative;wound, infertility \\
\hline Ipera, mpera & Psidium guajava & Antidiarrhoea, dysentery, \\
\hline Mnyara & Euphobia tirucalli & Pneumonia, cough \\
\hline Matolo & Plectranthus barbatus & Cough \\
\hline Kitolo & Coleus spp. & Constipation-impaction \\
\hline Iwonu & Ricinus communis & Laxative \\
\hline Mbatu & Nicotiana tabacum & mites, mange, ticks, eye \\
\hline Mosereka & Pentas spp. & Leaves-laxative \\
\hline Mring'onu & Alangium chinease & Anaplasmosis \\
\hline Kidamu, mriri & Erythrina abyssinica & Mastitis \\
\hline Mring'onu & Alangium chinease & Anaplasmosis \\
\hline Misonabari & Eucalyptus spp & all poultry diseases \\
\hline Pilipili kichaa & $\begin{array}{l}\text { Capsicum fruilenscen } \\
\text { Capsicum annuum }\end{array}$ & all poultry diseases \\
\hline Mnyaa & Euphorbia candelabrum & all poultry diseases ND \\
\hline \multicolumn{3}{|l|}{ Maasai (Paraquio) tribe } \\
\hline Ol girigiri & $\begin{array}{l}\text { Acacia pennata } \\
\text { Acacia brevispica }\end{array}$ & Worms, \\
\hline Eluai & Acacia drepanolobiu & Babesiosis \\
\hline Ol mukutan & Albizia anthelmintica & bark-mastitis, diarhoea, worms \\
\hline Ol suguroi & Aloe volkensii & Retained placenta, wounds \\
\hline Ol beresinjugi & Andropogan ischaemum & non-infectious diseases \\
\hline OI sagarami & Bauhimia thonningii & Eye treatment \\
\hline Ol amuriake & Carissa edulis & Worms, \\
\hline Ol senetoi & Cassia didymoborrya & leaf, constipation,diarrhoe \\
\hline Ol matasia & Clausena anisata & leaf-worms \\
\hline Ekirikiri & Erythrina abyssinica & Flower-eye infection \\
\hline Ol pongoni & Euphorbia candelabrum & Wounds, sores, ulces \\
\hline Ol engerianthus & Galium aparinoides & fruit-throat cancer \\
\hline Ol orien & Olea africana & leaf-eye, babesiosis \\
\hline Ol dule, ol onyonyong' $i$ & Ricinus communis & Mites, mange, diarhoea, retained placenta \\
\hline Ol ojongalami & Serbania aegypriaca & diarrhoea \\
\hline Ndulele & Solanum incanum & fruit-constipation, root-worms \\
\hline Ganyamda & Balenites aegyptiaca & mites, mange, worms, \\
\hline Ol ama & Ximenia americana & root-diarrhoea, wounds \\
\hline Igumu & Tephrosia vogelii & minyoo, mites, mange, ticks \\
\hline
\end{tabular}




\section{CONCLUSION AND RECOMMENDATION}

The study revealed that both men and women from the three livestock production systems in Tanzania performed varying livestock activities and had wealth of local knowledge on livestock breeds, management, diseases and treatments. Incorporation of this knowledge, skills and practices into project implementation programs through blending with modern technologics could improve livestock productivity and livelihood of the people. Efforts on identifying the patterns of use and opportunities for conserving the indigenous knowledge are recommended.

\section{REFERENCES}

Mtenga L.A, A. Katule and Kitalyi A.J., 1992. Development of Livestock Production system in Tanzania. Proceeding of DANIDA workshop on the role of Veterinary Profession. pg. 160-169.

Ole Lengisugi 1994. The Indigenous knowledge and sustainable development; Livestock Health care for Maasai pastoralists. A paper Presented at a conference a Indigenous knowledge and sustainable development, Morogoro Tanzania

Rutatora, D.F., 1994. The role of I.K. in improving and sustaining agriculture development in Tanzania. An overview. Proc. Conf. on Indigenous Knowledge and Sustainable Development, held on 15-16 Sept. 1994. SUA. Morogoro.

Shayo S.A. and Mlay G.1., 1986. The performance of the Livestock Industry in Tanzania 1972-1980's. Proceeding of $4^{\text {th }}$ TVA scientific conference 4:25.

Warner, K., 1991. Shifting Agriculture: Local technical knowledge and natural resources management in the humid tropics. Community Forestry Note No. 8, FAO, Rome. 